\title{
RACIAL INEQUALITY AND SEXIST OPPRESSION IN TONI MORRISON'S BELOVED
}

\author{
Amina Rashid, Md. Masud Rana \\ Faculty, English Language Institute, Jazan University \\ Jazan, Saudi Arabia \\ E-mail: aminarashidbd@gmail.com
}

Received: 2021-05-20

Accepted: 2021-06-02

\begin{abstract}
Morrison in her writings has keenly addressed racism and sexism as the two dominant social codes of untold sufferings of African-Americans in the United States. The manifestation of brutality and abuse of these two stereotypes in the name of racial indifference, superiority, prejudice or discrimination and sexual inequality, suppression, rape and other form of sexual violence has made her unparalled as the novelist of black experience. This study mainly examines the construction of racialized society and gendered identities in fictional text of Morrison's Beloved. The aim of the research is to analyze and explore how these identities are constructed in Beloved by using a feminist approach. The research finds that the imposed ideal of femininity is absorbed and patriarchy is assumed. Female's black characteristics are repressed both intra-communally and inter-communally. In the former, black female characters are not 'fitted' to white femininity as they strive for identity crisis even among the black. In the latter, they are whim of male dominance-subject of incest, rape and seduction. Though, women are doubly repressed, it is not the racial discrimination that threatens and jeopardizes black women identity rather a sheer domination of patriarchal power from within and without exaggerating debasing women life among the whites.
\end{abstract}

Keywords: postcolonial feminism, racism, slavery, patriarchy, gender discrimination

\section{Introduction}

Toni Morrison's novel Beloved has often been interpreted and evaluated as a body of work on racism and feminism and how these two issues settle Afro-American life among the white community. The novel depicts the Afro-American women as victims of both gender and racial discrimination (Nirupama \& Laishram, 2016). Beloved offers a fresh perspective on black life, their history and genealogy. The major focus is apartheid, slavery and racism, the psychological and socio-cultural subjugation of blacks over the ages. Morisson focuses on the damage that the black women characters doubly suffer through the construction of femininity in a radicalized society and explores the experience and roles of black women in a racist and male dominated society. She also shows the complex reality of being both black and female in a patriarchal society. According to Ru \& He (2016), "Morrison reflected miseries, abnormalities and distortions of the black women's feeling and mind under the oppressions of racism and sexism (p7)". The research focuses on Toni Morrison's novel 
Beloved and considers constructions of femininity and examines power relations with a view to breaking them down and show the extend of patriarchy.

\section{Literature Review}

Beloved (1987) unfolds the legacy of slavery and its trauma of African-Americans and their descendants. It is a harrowing novel about racism and sexist oppression and violence. The consequence of slavery and the condition of women in gender-biased socety are portrayed in Beloved. Slaves were treated as subhuman creatures and they received punishment as mutilation of the corspe (Ali, 2013). Morrison has shown the relations between blacks and whites in terms of slavery as well as examines the violence, sexual exploitation, and discrimination that supremacitists whites have perpetrated on grounds of racial supremacy (M'Baye, 2006). Though Beloved mainly illustrates the miserable lives of women caused by racial discrimation and sexual oppression, Morrison also highlights the inhuman condition of black men in the racial world (Dzregah, 2013). Paul D. is a fragmented and lost human being who has been utterly shaken by the inhumanity of slavery (Gallego, 2009). On the other hand, due to racism, black women are subordinate to white women in society and unlike white women; black women have lacked diference in the dominat society principally because of the stigma of race (Lewis, 1977).

African -Amercian women are "inferior" as a race and sexually objectified as women (Goza, 2020). According to Hooks (as cited in Ghaemmaghami, 2009) the sexual exploitation of the slave woman was even more dehumanizing than the racist exploitation of black women as hard laborers. She contends that the institutionalized sexism of the patriarchal white slaveowners created a social system that spared black males the humiliation of sexual assault and protected black male sexuality. However, such institutionalized sexism legitimized the sexual exploitation of black females. Hooks says, while institutionalized sexism was a social system that protected black male sexuality, it (socially) legitimized sexual exploitation of black females. The female slave lived in constant fear that any male, white or black, might single her out to assault and victimize (24).

The presence of black feminine characters in Morison's novels is represented as repressed race subject to male domination. In an interview with Mckay (1988), Morrison says, "I think black women are in a very special position regarding black feminism as advantageous one, what women generally define black women's role as the most repressed because they are both black and female (p. 48-49)." Nevertheless, female identity creates more acute problem than blackness. Blackness, a communal discrimination can be done but the macho man dominating within the society can hardly be undone. Therefore, black feminine characters are repressed, suppressed and consumed by different ways. For example: their white masters because of their blackness repress them, their own black people subjugate them, as they are female. They are slaves of slaves (Mageswari, 2018).

Picola the protagonist in Morrison's first novel The Bluest Eye (1970) is the victim of dual repression. Her familial ostracism is seen through the treatment of her parents, especially of her father. She is twice raped and impregnated by her own father. In The Bluest Eye, Pauline Breedlove, Geraldine, Maureen Peal, and Pecola are black characters who try to conform to an imposed ideal of femininity. They are absorbed and marginalized by the "cultural icons portraying physical beauty: movies, billboards, magazines, books, newspapers, window signs, dolls, and drinking cups" (Gibson, 1989). In trying to conform to the ideal of white femininity, the black women characters despise their blackness, which in turn leads to self- 
hatred. They see themselves through the eyes of white people and their worship of white beauty has destructive effects on their own community.

All the accepted norms of women life emerge as a rebel, a mocker, and a wanton, sexual seductress and suffers the consequences of her choices because she is 'neither white nor male and that all freedom and triumph was forbidden for them.' Therefore, it shows it is not racial segregation but a phallocentric tradition has succeeded in suppressing women's voice.

Sexism in Beloved is dealt with Sethe becomes a victim of sexual harassment by the white slave masters. Sethe, an escaped slave on confronting the white slave master kills her child rather than letting it into their hands. Morrison interweaves racial and sexual consciousness in Beloved. Therefore, her brutal act of killing her infant is not only an impact of slavery or racism but also a vile form of patriarchy which operates underneath.

On the other hand, Mohammed (2018) portrays the dehumanizing effect of slavery on the characters and how the traumatic memory of the past has crippled them physically, psychologically and emotionally to adapt the present. "Sethe is the embodiment of a traumatic and devouring past, a character in whose personality, the reader perceives the painful loss of a true maternal love. The weight of the past has diminished the possibility of a meaningful present and a promising future. Paul D tells Sethe that together they have "move yesterday than anybody. We need some kind of tomorrow" (Morrison, Beloved, 1997, p. 273)." (p. 50). Beloved shows the mental condition of the characters, who were former slaves. The slavery has devastated them physically, mentally, emotionally and spiritually (Kesur 2019).

\section{Research Method}

The qualitative descriptive method has been used to describe and analyze data collected from both primary and secondary sources to reach the objective of the study. For this study, Beloved is taken as a primary source and the text is analyzed by using a feminist postcolonial approach. Post-colonial feminist theory define women as subjugated by both patriarchy and colonial power. The quotations, texts, sentences and words relevant to the objective of this research have been identified, examined and illustrated through a thematic and textual analysis approach. Secondary research includes Morrison's interviews, books, and collections of critical essays, research papers and articles available in library of bookshops. Useful websites and online journals are also used to search for relevant data for the study. Finally, secondary data related to the main idea has been meticulously scrutinized, and explained. On the other hand, a thorough review of literature has been conducted to provide contributions of other prominent writers and critiques about the subject matter.

\section{Results and Discussion}

\subsection{Racial Inequality}

Morrison portrays the dreadful condition of racial discrimination between the white masters and the black slaves. In fact, Beloved represents the time before and after the abolishment of slavery. Because of the acrimonious racial discrimination prevailing in that American society, Morrison depicts the inhumane and brutal circumstances of the system of slavery.

The racist whites were so mean to sanctify the marriage between the slaves so that they could not claim anything - their lives, their family, and their children. When Sethe and Halle got married, the white masters did not recognize their marriage. To have some senses of 
celebration for their socially, religiously and legally unsanctified marriage, Sethe sewed a dress from very old clothes.

The supremacists did not allow the slaves to assert things: Baby Suggs got eight children from six different fathers. Nevertheless, she lost all of her children while they were young, except Halle, whom she lost ultimately. Sethe also recollects how Halle used to treat hermore like a brother rather than one who could lay claim to her. Sethe and Halle were unable to lay claim to each other because their own lives were not their property. Stealing her milk as well as raping her in front of her husband without any protest from his part indicates the loss of manhood and the powerlessness to claim and save his family. Eventually Halle went mad after seeing all these brutality in front of his eyes. The slaves were never able to own anything. The sense of possession that comes through love and marital ties is concealed by the abnormal ownership of slavery.

The racist whites were the "definers". So "definitions belonged to the definers- not the defined" (Morison, 1988: 190). Schoolteacher beat Sixo-the black nigger, just to remind him that he had no right to give "definitions".

Identity crisis is another phenomenon of Racism. The characters in Beloved suffer from the absence of self-knowledge and self-recognition under slavery. Mr. Garner never called baby Suggs by any name at all. The absence of a name signifies the denial of her humanity. Paul $D$ wonders about the value of masculinity bestowed on him by a white master. He questions his manhood. He recalls the benevolence of Mr. Garner, his owner, who regarded him and the other male slaves at Sweet Home as men. Nevertheless, this turned out to be a mean trick to fool the slaves. Schoolteacher, a more malicious slave owner, did not believe he was a man. Now Paul D does not believe it either, if he were really a man, he could break his relationship with Beloved. He takes the coward's route to deal with Beloved and Sethe. It points to the shortcomings of even Mr. Garner's "enlightened" slavery. Once Garner died, masculinity proved terrifyingly easy to take away. In fact, the slave's dignity still had its origin in an outside source and was therefore meaningless.

"In Morrison's novel, it is realized that the character's self-esteem and self-worth have been denigrated or even eliminated by racism, marginalization and oppression. Their skin color or more clearly, their degree of blackness shows their value. For instance, the lightskinned blacks had a better position in society than darker ones. It was not an idea just among the white majority, but even blacks treated one another differently based on the degree of their blackness. These opinions were transferred from one generation to the next. Therefore, considering Morrison's characters, it becomes clear that racism and oppression are not limited to an individual's life, but also influence other generations." (Shahrezaee \& Ladani, 2014: 19)

The brutality of racism and slavery is shown in Paul D's memories of the chain gang where he was forced to work. The men on the chain gang slept in wooden boxes that were sunk into a deep ditch a thousand feet long. Paul $D$ locked up his harsh memories "into a tobacco tin lodged in his chest"(Morrison, 1988: 113) which "nothing in this world could pry it open." (Morrison, 1988: 113)

Sethe kills her daughter to save her from the brutality of slavery, to exclude her from the consequences of slavery. Perhaps, the most horrible experience of slavery is a mother's killing of her children with an intention of keeping them away from slavery. Sethe gives a physical death to her daughter rather than the psychological death. Sethe states, "If I hadn't killed her, she would have died and that is something I could not bear to happen her" (Morrison, 1988, p.200). This, in fact, exemplifies the reality of the Fugitive Slave Law, which permitted slave owners to hunt down escaped slaves and pull them back into slavery. In Sethe's case, 
Schoolteacher came for her and her children. Sethe's act of killing one child and attempting to kill the others is a strong statement about the cruelty of slavery and a mother's love: she would rather see her children dead than enslaved; Sethe "carried, pushed, and dragged them through the veil, out, away, over, there where no one could hurt them. Over there. Outside this place, where they would be safe." Her endeavor to transport the children away to "where no one could hurt them" (Morrison, 1988: 163).

According to Fuston-White (2002), it was the consequences of slavery that led Sethe to kill her child, compelled her to accomplish such a vicious crime. She states, "It was not madness, but the reality of slavery, that drove Sethe to kill her child, fully aware of the act and its brutality, as well as its compassion" (p.464).

"Another example of infanticide is Charlotte Brooks' slave narrative in American Slaves Tell Their Stories. In this book, Rogers Albert makes six interviews with slaves. One of them is Charlotte Brooks. Like Sethe in Beloved, Aunt Charlotte kills her children. She thinks that it is better for them to die before becoming slaves. She mentions that: "They died for want of attention. I used to leave them alone half of the time. Sometimes old mistress would have someone to mind him or her until they got so they could walk, but after that, they would have to paddle for themselves. I was glad the Lord took them, for I knew they were better off with my blessed Jesus than with me" (8)" (as cited in Shahrezaee \& Ladani,2014: 20 ).

The white superiority and black inferiority is also vividly portrayed in The Bluest Eye. The difference between colored people and niggers were easily identifiable. Colored people were neat and quiet; niggers were dirty and loud. "Long hours" Pecola "sat looking at the mirror, trying to discover the secret of the ugliness, the ugliness that made her ignored or despised at school, by teachers and classmates alike." (Morrison, 1970: 45) She has seen "the distaste" for the "blackness" "lurking in the eyes of all white people." (Morison, 1970: 49) In the eyes of white people "under every dark skin was a jungle" (Morison, 1988: 198), but "it wasn't the jungle blacks brought with them to this place from the other (livable) place. It was the jungle white folks planted in them" (Morison, 1988: 198).

The blacks because of their color and race are deprived of self-respect, honor, inclusion, equality, identity and even ownership of their own self, family or children. They feel uneasiness and otherness in the white ruled, white superior society. Even when they became free, they had to bear the effects of slavery and racism as they lost their individuality, the sense of freedom; and the burden of memories kept them under pressure all the time. Paul D asked Stamp Paid, "Tell me this one thing. How much is a nigger supposed to take? Tell me. How much?" (Morrison, 1988, p. 235) "All he can, said Stamp Paid. "All he can." until death. (Morrison, 1988: 235)

\subsection{Sexist Oppression}

Sexist oppression is as strong as racism in the lives of enslaved black women, which is institutionalized and socially structured by patriarchy. Racist exploitation of black women as workers either in the fields or in domestic household was not as de-humanizing and demoralizing as the sexual exploitation. The female slave lived in a constant awareness of her sexual vulnerability and in perpetual fear that any male, white or black, might single her out to assault and victimize (Hooks, 1982; Boudreau, 1995).

In Beloved, Morrison illustrates gender discrimination between male and female slaves. She emphasizes, "Particularly the brutal form of double oppression suffered by black women on account of their race and gender" (Chakravarty, 2008: 178). Society approves certain roles, actions, behaviors and features for male and female that result in sexual inequalities. 
Sexual inequality is examined here with special reference to feminism. Feminist theory focuses on gender politics, gender relations, power issues and sexuality to criticize this inequality. "Inequality comes from the refutation of equal rights. The main obstacle to equality is sexism. Women are considered the first suppressed group, facing this sexism; women's suppression is most pervasive and deepest. No man will relinquish gender advantage as no white relinquishes racist advantage" (Shaheen \& Nazir, 2014: 97).

Gender discrimination is vividly presented in Beloved. The center of our attention are the female slaves, whose sufferings are twofold. "Not only does their skin color push them toward the margin, but also their gender causes their being doubly marginalized" (Shahrezaee \& Ladani, 2014: 19).

Women were treated rudely not only in the hands of white masters but also by their own community people. The community's envy of Baby Suggs, their refusal to celebrate life and become resentful of her generosity show their anxieties, their fears, their disgusts to accept a female slave who tries to represent herself as an individual self in the society. The community is also partially responsible for Sethe's infanticide who out of jealousy did not inform baby Suggs about the Schoolteacher's arrival to catch Sethe and her children. Their hatred of Sethe, a female slave, who tried to break the social norm, led Sethe and Denver stay in isolation for long years, and they had to stand alone and did not go to the community for anything.

Patriarchy considers female body as an object of commerce. We find Sethe, as a free woman out of bondage, also experienced sexual abuse because she could not afford to pay for the engraving of her daughter's grave. She was forced to use her body as an object of commerce. The commercialization of the female body is quite evident in the bargain the engraver proposes to Sethe, "Ten minutes, he said. You got ten minutes I'll do it for free." (Morrison, 1988, p. 5). With ten minutes sex she could engrave only seven letters "Beloved". However, she wanted to engrave "Dearly Beloved" and "for twenty minutes, a half hour, say, she could have had the whole thing". (Morrison, 1988: 5).

In Ain't I a Woman: Black Women and Feminism (2007), Hooks states that:

"As far back as slavery, white people established a social hierarchy based on race and sex that ranked white men first, white women second, though sometimes equal to black men, who are ranked third, and black women last. What this means in terms of the sexual politics of rape is that if one white woman is raped by a black man, it is seen as more important, more significant than if thousands of black women are raped by one white man." (52)

Therefore, black women are in the periphery of social rank. In Beloved too, Sethe appears as an inferior black woman who greatly suffers mistreatment. Because of her social status, not only her white masters but also other people in society exploit her as they wish. Sethe seems to have no right to defend herself.

In Beloved, Morrison emphasizes the dehumanizing effects of slavery especially on female slaves. Sethe is raped, mistreated, and violated. She mentions:

"After I left you, those boys came in there and took my milk. That is what they came in there for. Held me down and took it. I told Mrs. Garner on em. She had that lump and could not speak but her eyes rolled out tears. Them boys found out I told on em. Schoolteacher made one open up my 
back, and when it closed, it made a tree. It grows there still." (Morrison, 1988, p. 16).

Vulnerability of female body is another phenomenon of patriarchy. Women cannot protect themselves. Though they had to give severe physical labor, they were also the victims of their white masters' wishes and urges. They were not the owner of their own bodies; they were forced to make their bodies available whenever their masters wanted. As if their bodies were the possessions of their masters' and they were incapable to protect it. They were treated as sexual objects in the hands of white masters. Even the white wives (as they are female in the patriarchal society) did not have any power to stop their husbands from doing this violations and rapes. Stamp Paid went to his young master's wife (as his wife Vashti "every now and then she be gone all night" (Morrison, 1988, p. 233) to satisfy her master's sexual desires) with the hope that "she might stop it, but it went right on." (Morrison, 1988: 233).

Stamp Paid, a typical man, the prototype of the society could do nothing to stop the violation of his wife but he could show his wrath to the powerless, helpless, feeble, week woman. "I looked at the back of her neck... I decided to break it." (Morrison, 1988: 233).

'Death' is the only solution to escape the never-ending cycle of subjugation and discrimination. This is the tragedy of the black women in the society, which is manipulated by patriarchy and racism. Sethe's eldest daughter Beloved, Stamp Paid's wife Vashti are the embodiments of this deprivation.

Female black slaves were seen as breeders - the reproducers of more slaves by their white masters. Though Sethe is a slave, she is still valued for her fertility by Schoolteacher. Children of every black people were the property of slave masters and they were being raised to do the work that was badly needed in whites' family. For instance, Baby Suggs has eight children with six different men. The narrator says, "Her two girls, neither of whom had their adult teeth were sold and gone nor she had not been able to wave good bye." (Morrison, 1988, p. 23).

The dual policy of patriarchy is that the male slaves suffered from racial discrimination but the female slaves were subjected to both racial and gender discrimination (Chakravarty 2016, Mageswari, 2018). Whereas the male slaves were mostly limited to working in the fields, the female slaves were subjected to both household as well as plantation work. As punishment they could beat both male and female as well as they could rape one, so that the female slaves could receive dual punishment.

Because of their race and gender, their sufferings were worst in compare to the male slaves. Hira Ali (2013) says, "Lives of woman slave were much worst as compared to male slaves due to two reasons. Firstly, husbands of slave woman were taken away or sold by the white masters. Secondly, black woman were abused and violated through rape. White man kept sexual relations with black woman in order to increase their assets." (p. 1421)

\section{Conclusion}

Being a black feminist and having first-hand experience Morrison has vividly documented the agony of racism and sexism in white dominated American society. The novel Beloved shows the miserable life of Afro- American women who are doubly oppressed by both racism and sexism. The untold and unvoiced plight of racism, slavery and sexism in the dominant white-skin culture has made the novel unique. The conflict between the whiteness and blackness and the superiority of whiteness over blackness is painstakingly 
portrayed in Beloved. The Afro-American black people are considered merely slave rather than human of flesh and blood. They have been deprived from all human rights, and deliberately hated, raped, and even killed. On the other hand, black feminine has been dehumanized because of their sex and color. They have been made slave and forced into sex slavery by both white and black male. Unlike black male who are only racialized, black female are victimized by racial and sexual oppression and the latter is considered a great threat to the freedom of black women. For them racial equality does not entail all human rights and freedom as like as colored women in socially constructed sexist mind-set of America. No matter whether white or non-white women, everyone is conditioned to accept femaleness as inferior / sexism as natural. Therefore, black famine is enslaved and sexually oppressed by their racist and sexist white master and at the same time forced to be silent as sexually inferior by black male patriarchy. According to Hooks (2007), the struggle to end racism and the struggle to end sexism were naturally intertwined that to make them separate was to deny a basic truth of our existence, that race and sex are both immutable facets of human identity.

\section{References}

Ali, H. (2013). Gender Analysis in Toni Morrison's Beloved and Sula. Middle East J. Sci. Res., 16(10), 1419-1423. https://www.idosi.org/mejsr/mejsr

Boudreau, K. (1995). Pain and the Unmaking of Self in Toni Morrison's "Beloved". Contemporary Literature, 36(3), 447-465. DOI: 10.2307/1208829

Chakravarty, R. (2008). Toni Morrison: Imagined Grace. Feminism and Contemporary Women Writers: Rethinking Subjectivity. New York: Routledge, p. $164-184$.

Dzregah, A. E. (2013). Men and their Portrayal in Beloved: The Framing of Black and White Masculinities in a Slave-Owning World. European Scientific Joural, ESJ, 9(19). https://doi.org/10.19044/esj.2013.v9n19p\%p

Fuston-White, J. (2002). From the Seen to the Told: The Construction of Subjectivity in Toni Morrison's Beloved. African American Review, 36(3), 461-473.

Gallego, M. (2009). What Does it Mean to be a Man? Codes of Black Masculinity in Toni Morrission's Paradise and Love. Revista de Estudios Norteamericanos, 14(49-65)

https://idus.us.es/bitstream/handle/11441/31829/1/What\%20does\%20it\%20Mean\%20to\% 20Be\%20a\%20Man.pdf?sequence=1

Ghaemmaghami, C. A. (2009). Milk Enough for All: The African-American Woman's Quest for Identity and Authority in Toni Morrison's "Beloved". Dissertations, Theses, and Masters Projects. Paper 1539625561. https://dx.doi.org/doi:10.21220/s2-k6ap-7d55

Goza, M (2020). African-American Women and the Effects of Racism and Sexism in 2020 v. in Beloved. University of North Georgia. Retireved on May 24, 2021 from https://digitalcommons.northgeorgia.edu/cgi/viewcontent.cgi?article=1013\&context $=$ projbe

Gibson, D. B. (1989). Text and Counter text in Toni Morrison's The Bluest Eye. Lit: Literature Interpretation Theory, 1(1), 19-32. https://doi.org/10.1080/10436928908580021

Hooks, B. (1982). AIN'T I A WOMAN: Black Women and Feminism. London: Pluto Press.

Kesur, B. (2019). Toni Morrison's Beloved: A Critique of Institutionalized Dehumanization. International Journal of Research in Social Sciences, 9(6), 821-831. http://www.ijmra.us

Lewis, D. (1977). A Response to Inequality: Black Women, Racism, and Sexism. Signs, 3(2), 339361. Retrieved May 26, 2021, from http://www.jstor.org/stable/3173288 
Mageswari, R. U. (2018). Gender Discrimination in Toni Morrison's Beloved. Language in India, 2, 331-335. www.languageinindia.com

McKay, Y., N. (1988). Critical Essays on Toni Morrison. U.S.A: Library of Congress, 48-49.

Mohammed, M. (2018). The Impact of Slavery in Toni Morrison's Beloved: From the Communal to the Individual. International Journal of Applied Linguistics and English Literature, 7(6). 48-51. http://dx.doi.org/10.7575/aiac.ijalel.v.7n.6p.48

Morrison, T. (1970). The Bluest Eye. London: Chatto and Windus.

Morrison, T. (1987). Beloved. London: Picador.

Morrison, T. (1988). Beloved. London: Picador.

Nirupama, K., \& Laishram, S. (2016). Gender and Race in Toni Morrison's Beloved. Journal of Higher Education and Research Society: A Refereed International, 4(2), 200-208 https://herso.org/

Shahrezaee, M. A. \&, Ladani, Z. J. (2014). Toni Morrison's Beloved and the Bluest Eye: A Cultural Materialistic Approach. International Letters of Social and Humanistic Sciences, 30, 17-23. DOI: 10.18052/www.scipress.com/ILSHS.30.17

Shaheen, M. A., \& Nazir, K. (2014). The Study of Gender in Toni Morrison's Beloved. Interdisciplinary Journal of Contemporary Research in Business, 6(1), 196-212. https://journal-archieves36.webs.com/196-212may14.pdf

Ru W., \& He, G. (2016). The Characteristics and Growth of the Black Women Embodied in Beloved. Studies in Literature and Language, 13(1). 8-12. DOI: 10.3968/8532 